\title{
OPTIMIZATION PROBLEMS OF MATHEMATICAL MODELLING OF A BUILDING AS A UNIFIED HEAT AND POWER SYSTEM
}

\author{
Yuri A. Tabunshchikov, Marianna M. Brodach \\ Moscow Architectural Institute (State Academy), Moscow, RUSSIA
}

\begin{abstract}
The mathematical model of a building as a single heat energy system by the decomposition method is represented by three interconnected mathematical models: the first is a mathematical model of the energy interaction of a building's shell with an outdoor climate; the second is a mathematical model of energy flows through the shell of a building; the third is a mathematical model of optimal control of energy consumption to ensure the required microclimate. Optimization problems for three mathematical models with objective functions are formulated. Methods for solving these problems are determined on the basis of the calculus of variations and the Pontryagin maximum principle. A method for assessing the skill of an architect and engineer in the design of a building as a single heat energy system is proposed.
\end{abstract}

Keywords: building as a single heat power system, mathematical model, heat consumption optimization, outdoor climate, building envelope, maximum principle

\section{ОПТИМИЗАЦИОННЫЕ ЗАДАЧИ МАТЕМАТИЧЕСКОГО МОДЕЛИРОВАНИЯ ЗДАНИЯ КАК ЕДИНОЙ ТЕПЛОЭНЕРГЕТИЧЕСКОЙ СИСТЕМЫ}

\author{
Ю.А. Табунщиков, М.М. Бродач \\ Московский архитектурный институт (государственная академия), г. Москва, РОССИЯ
}

\begin{abstract}
Аннотация: Математическая модель здания как единой теплоэнергетической системы методом декомпозиции представлена тремя взаимосвязанными математическими моделями: первая математическая модель энергетического взаимодействия оболочки здания с наружным климатом; вторая - математическая модель энергетических потоков через оболочку здания; третья - математическая модель оптимального управления расходом энергии на обеспечения требуемого микроклимата. Сформулированы оптимизационные задачи для трех математических моделей с целевыми функциями. Определены методы решения этих задач на основе вариационного исчисления и принципа максимума Понтрягина. Предложен метод оценки мастерства архитектора и инженера при проектировании здания как единой теплоэнергетической системы.
\end{abstract}

Ключевые слова: здание как единая теплоэнергетическая система, математическая модель, оптимизация теплопотребления, наружный климат, оболочка здания, принцип максимума

Thermal engineering design of the building is based on the tasks of determining the consumption of thermal energy required to maintain optimal or permissible thermal conditions in the room. This problem can be considered as optimization, if we take as the objective function the minimization of the energy expenditure spent on ensuring the optimal or permissible thermal regime, i.e. as finding a minimum of the following equation:

$$
Q=\int_{\tau_{1}}^{\tau_{2}} C_{H} Q_{H} d \tau+\int_{\tau_{3}}^{\tau_{4}} C_{x} Q_{x} d \tau \rightarrow \min ,(1)
$$


where $Q_{H}, Q_{x}$ are the consumption of thermal energy for heating and cooling buildings, $W ; C_{H}, C_{x}$ are the cost of a unit of heat and a unit of cold, rubles $/ W ;\left(\tau_{2}-\tau_{1}\right),\left(\tau_{4}-\tau_{3}\right)$ are building heating and cooling periods, hours.

When minimizing energy costs, it is necessary to understand that these costs are part of the reduced costs related to the operational component of the reduced costs. The criterion for choosing one or another technical solution can be only a minimum of the costs presented.

At the same time, minimizing operating costs is a critical energy challenge. A typical situation is this: organizing heating or cooling of a building and considering the building as a single energy system, we get that the required energy consumption will vary greatly depending on the shape of the building, the indicators of heat and sun protection, the type of heating or cooling system, etc. Each option has some advantages and some disadvantages, and, due to the complexity of the situation, it is not immediately obvious which of them is preferable finally and why. In order to clarify the situation and help the decision maker, a series of mass calculations is carried out, which can be replaced by the solution of optimization problems.

The mathematical model of the building as a single heat energy system was considered in detail in [1]. In accordance with the principles of system analysis and decomposition, we will present the mathematical model of the building as a single heat energy system with the following three mathematical models.

The first is a mathematical model of the energy interaction of the building envelope with the directed energy impact of the outdoor climate. The heat and power characteristics of an external climate acting on a building can be expressed by the following equations:

$$
\begin{gathered}
Q_{t}=c \rho \operatorname{Vm}\left(t_{b}-t_{H}\right), \quad W \\
Q_{v}=c \rho\left(t_{b}-t_{H}\right) \sum F_{i} v_{i}, \quad W, \\
Q_{I}=\sum J_{i} F_{i}, \quad W
\end{gathered}
$$

where $Q_{t}, Q_{v}, Q_{I}$ are energy exposure to outside air, wind and solar radiation; $c \rho$ is volumetric heat capacity of outdoor air, $\mathrm{kJ} /\left(\mathrm{m}^{3} \cdot{ }^{\circ} \mathrm{C}\right) ; \mathrm{V}$ is building volume, $m^{3} ; F_{i}$ is area of $\mathrm{i}$-th outer surface, $m^{2} ; t_{B}, t_{H}$ are temperatures of the internal and external air, ${ }^{\circ} \mathrm{C} ; m$ is air exchange rate, $1 /$ hour; $v_{i}$ is air speed, $\mathrm{m} / \mathrm{s} ; J_{i}$ is the intensity of the solar radiation incident on the surface of the $\mathrm{i}$-th fence, $\mathrm{W} / \mathrm{m}^{2}$;

The second mathematical model is a mathematical model that describes heat flows through the shell of a building.

The third mathematical model is a mathematical model that describes the energy contained in the volume of a building.

In accordance with the presentation of the mathematical model of the building as a single energy system and its presentation by three interconnected mathematical models, we formulate the following three optimization problems.

Here we dwell in more detail on the solution of the first optimization problem; the solution of the second and third optimization problems can be found in [1].

The first task of optimally taking into account the energy impact of the external climate on the building envelope can be formulated as follows: to determine the shape of the building envelope so that the positive impact of the outdoor climate on it can be maximized and its negative impact can be neutralized as much as possible.

The objective function is to optimize the accounting for the heat and energy impact of the external climate in the heat balance of the building.

Optimization of the shape of the building can be performed for various climatic periods of the year: for the coldest five-day period in order to reduce the estimated capacity of the heating system; for the heating period in order to reduce energy costs for heating; for the hottest month in order to reduce the installation capacity of the air conditioning system; for the cooling period of the building in order to reduce energy costs for cooling; for the accounting year in order to reduce energy costs for heating and cooling the building. There may be other climatic periods, depending on the problem being solved. 
The obtained optimization problem, which reduces to finding the equation of the directrix and the height of a curved cylindrical surface, relates to isoparametric problems of the calculus of variations [2, 3]. In accordance with the methodology of isoparametric problems [2], we need to determine the extremum of a function that describes the heat balance of a building with a curved surface:

$$
\begin{aligned}
& Q= \\
& =Z H \int_{0}^{2 \pi}\left[q_{E n c}(\varphi)\left(1-P_{W}\right)\right. \\
& \left.+q_{W}(\varphi) P_{W}\right] \sqrt{r^{2}(\varphi)+r^{\prime 2}(\varphi)} d \varphi \\
& ++\frac{1}{2}\left[q_{\text {roof }}\left(1-P_{\text {roof }}\right)\right. \\
& \left.+q_{\text {roof }}^{g l} P_{\text {roof }}\right] \int_{0}^{2 \pi} r^{2}(\varphi) d \varphi \\
& ++\frac{1}{2} q_{f l} \int_{0}^{2 \pi} r^{2}(\varphi) d \varphi \\
& =Z H \int_{0}^{2 \pi} q_{1}(\varphi) \sqrt{r^{2}(\varphi)+r^{\prime 2}(\varphi)} d \varphi \\
& +q_{2} \int_{0}^{2 \pi} r^{2}(\varphi) d \varphi,(3)
\end{aligned}
$$

where we have

$$
\begin{gathered}
q_{1}(\varphi)=q_{E n c}(\varphi)\left(1-P_{W}\right)+q_{W}(\varphi) P_{W} ; \\
q_{2}=\frac{1}{2}\left[q_{\text {roof }}\left(1-P_{\text {roof }}\right)+q_{\text {roof }}^{g l} P_{\text {roof }}+q_{f l}\right] ;
\end{gathered}
$$

$Q$ is the amount of heat required to maintain a given room temperature, $W ; q_{E n c}(\varphi), q_{W}(\varphi)$ are specific heat fluxes passing respectively through the external vertical glazed and glazed enclosing structures, calculated taking into account the directed influence of solar radiation and wind (air filtration) in polar coordinates, $\mathrm{W} / \mathrm{m}^{2} ; q_{\text {roof }}, q^{g}$ roof are specific heat fluxes, respectively, through the unglazed and glazed parts of the coating, calculated taking into account the effect of solar radiation, $W / \mathrm{m}^{2} ; q_{f l}$ is specific heat flow through the building envelope of the first floor, $W / \mathrm{m}^{2} ; P_{W}$ is glazing coefficient of the vertical building envelope; $P_{\text {roof }}$ is glazing coefficient; $F_{0}$ is total floor area of the building, $m^{2} ; H$ is floor height, $m ; Z$ is the number of floors; $r(\varphi)$ is radius (directrix equation), $m ; \varphi$ is angle.

We determine the extremum of function (3) from the equation:

$$
F_{0}=\frac{1}{2} Z \int_{0}^{2 \pi} r^{2}(\varphi) d \varphi
$$

Here $F_{0}, H, q_{1}(\varphi), q$ are given values; $r(\varphi), Z$ are unknown variables that need to be determined. In order to determine the necessary initial condition in the isoparametric problem by finding the extremum of the function from the equation, we present an additional function [2]:

$$
J^{*} \int_{0}^{2 \pi}\left(Q_{1}+\lambda Q_{2}\right) d \varphi=\int_{0}^{2 \pi} Q d \varphi Z,
$$

where we have

$$
\begin{gathered}
Q=Q_{1}+\lambda Q_{2} \\
Q_{1}=Z H q_{1}(\varphi) \sqrt{r^{2}(\varphi)+r^{\prime 2}(\varphi)}+\frac{1}{2} q_{2} r^{2}(\varphi) \\
Q_{2}=Z r^{2}(\varphi)
\end{gathered}
$$

$\lambda$ is some constant to be defined.

For the additional function (6), we write the Euler equation for the variable $r(\varphi)$ :

$$
\frac{\partial Q}{\partial r}-\frac{d}{d \varphi}\left(\frac{\partial Q}{\partial r^{\prime}}\right)=0
$$

and differential equation (6) through $Z$ :

$$
\frac{d J^{*}}{d Z}=0
$$


As a result, we get the system of equations:

$$
\begin{gathered}
Z H q_{1}(\varphi)\left[\frac{r}{\sqrt{r^{2}+r^{\prime 2}}}+\right. \\
\left.\frac{r^{\prime \prime}\left(r^{2}+r^{\prime 2}\right)-r^{\prime 2}\left(r+r^{\prime}\right)}{r^{2}}\right]+Z H q_{1}^{\prime}(\varphi) \frac{r}{\sqrt{r^{2}+r^{\prime 2}}}+ \\
\left(q_{2}+2 \lambda Z\right) r=0(10) \\
\int_{0}^{2 \pi}\left[H q_{1}(\varphi) \sqrt{r^{2}+r^{\prime 2}}+\lambda r^{2}\right] d \varphi=0
\end{gathered}
$$

Therefore, to determine $\mathrm{r}(\varphi), \mathrm{Z}$, and $\lambda$, we have equations (10) and (11) and the isoparametric condition (5), and to determine the unknown variables $\mathrm{C}_{1}$ and $\mathrm{C}_{2}$ in the general solution of the Euler equation, we have boundary conditions:

$$
r(0)=r(2 \pi), \quad r^{\prime}(0)=r^{\prime}(2 \pi)
$$

Let us take a special case of solving the optimization problem for $q_{1}(\varphi)=$ const. Then

$$
r(\varphi)=\text { const, } r^{\prime}(\varphi)=0 \text {. }
$$

Equation (10) will be as follows:

$$
Z H q_{1}+\left(q_{2} 2 \lambda Z\right) r=0
$$

Equations (5) and (11) lead to

$$
F_{0}=\pi Z r^{2} ; \quad H q_{1} r+\lambda r^{2}=0
$$

The solution of system (12) and (13) gives

$$
r=\sqrt[3]{\frac{H F_{0} q_{1}}{\pi q_{2}}}
$$

Now we pass to the second optimization problem. Note that the second, as well as the third optimization task, can have different objective functions depending on the goal set by the researcher - architect or engineer.
The peculiarity of the second optimization problem of energy flows through the building envelope is due to the fact that heat transfer in winter is determined by the stationary mode, and in the summer there is a significantly unsteady mode. One of our frequent decisions showed [4] that in this case the fencing material should have a minimum coefficient of thermal conductivity and the highest possible value of volumetric heat capacity.

It seems that to some extent this condition is satisfied by wood structures. However, here there is an interesting technical problem of creating a material with low thermal conductivity and high volumetric heat capacity. An optimization problem can also be posed on the optimal arrangement of layers in a multilayer structure.

You can also consider the optimization problem associated with the fact that in summer in a warm climate the temperature of the indoor air due to heat from solar radiation through the windows exceeds the temperature of the outdoor air. In this case, the heat flux is directed from the room and the excess of the role of thermal protection of the fence will increase the temperature of the indoor air. Here, the goal function is to minimize the temperature difference between the outdoor and indoor air and consists in finding such a ratio between the heat and sun protection of the building envelope and the air exchange rate at which the contribution of solar radiation to the room's thermal regime is minimized. It was found that the value of the heat transfer resistance of the external building envelope does not affect the thermal regime of the room, if the following equation is fulfilled:

$$
\begin{gathered}
\frac{F_{W}}{R_{0, W}}\left(\frac{\rho_{w l}}{\alpha_{\text {out }, w l}}-\frac{\rho_{w}}{\alpha_{\text {out }, w}}\right)+C_{V} \lambda_{V} V_{R} \frac{\rho_{w l}}{\alpha_{o u t, w l}}- \\
\beta F_{W}=0,
\end{gathered}
$$

where $R_{0, W}, F_{W}, \rho_{\mathrm{w}}, \alpha_{o u t, w}$ are the resistance to heat transfer of the window, $\mathrm{m}^{2} \cdot{ }^{\circ} \mathrm{C} / \mathrm{W}$; window area, $\mathrm{m}^{2}$; the absorption coefficient of solar radiation and the heat transfer coefficient of the outer surface of the window, $W /\left(m^{2} \cdot{ }^{\circ} \mathrm{C}\right) ; \rho_{\mathrm{wl}}, \alpha_{\mathrm{out}, \mathrm{wl}}$ are 
the absorption coefficient of solar radiation and the heat-transfer coefficient of the outer surface of the wall, $W /\left(m^{2} \cdot{ }^{\circ} \mathrm{C}\right) ; C_{V}, \lambda_{V}, V_{R}$ are the volumetric heat capacity of the air $\left(\mathrm{kJ} /\left(\mathrm{m}^{3} \cdot{ }^{\circ} \mathrm{C}\right)\right)$, air exchange rate $\left(h^{-1}\right)$, volume of the room $\left(\mathrm{m}^{3}\right) ; \beta$ is the coefficient of penetration of solar radiation through a permeable fence, taking into account its shadowing by a sun-protection device; $\mathrm{J}$ is the average daily value of the intensity of the total solar radiation, $\mathrm{W} / \mathrm{m}^{2}$.

Equation (14) corresponds to such an energy state at which the temperature inside the room is equal to the conditional temperature of the outdoor air. And consequently, the building envelope separates two media with the same temperature conditions.

We now formulate the third optimization problem as follows: find such a control of energy consumption $Q(t)$ when heating or cooling a room from temperature $t_{0}$ to temperature $t_{1}$ and such a solution to the system of equations of thermal balance of a given building's building as a single energy system that satisfies the initial conditions for $\tau=0 T=t_{0}$, for which the functional takes the smallest possible value.

$$
W=W=\int_{t_{0}}^{t_{1}} Q(t) d t
$$

The solution to this problem was obtained by the method of Academician Pontryagin as a problem of optimal control and presented in $[3,5]$. Based on the results of solving the problem of optimal control of the energy expenditure spent on heating or cooling the room, it was concluded: the minimization of energy costs for heating or cooling the premises is achieved if the transition time from the initial room temperature to the desired end the room temperature is minimal (the principle of "maximum performance").

As a result of solving optimization problems, it becomes possible to evaluate the skill of the architect and engineer when designing a building as a single heat and power system using the following equation (for example, when choosing the shape and orientation of a building envelope):

$$
\eta=Q_{e f f} / Q_{a c c}
$$

where $Q_{\text {eff }}$ is building energy consumption with optimal consideration of the directed action of the outdoor climate; $Q_{a c c}$ is energy consumption of the building accepted for design.

If, for example, the value of $\eta$ is 0.5 , then we can assume that the architect did not choose the shape of the building well enough and did not use the positive directional energy impact of the outdoor climate. In the other case, if, for example, $\eta=0.8$, then things are much better.

A similar estimate is possible for the second and third optimization problems.

\section{REFERENCES}

1. Tabunshchikov Yu.A., Brodach M.M. Matematicheskoe modelirovanie i optimizacija teplovoj jeffektivnosti zdanij [Mathematical modeling and optimization of the thermal efficiency of buildings]. Moscow, AVOK-PRESS, 2002, 194 pages.

2. Elsgolts L.E. Differencial'nye uravnenija i variacionnoe ischislenie [Differential equations and calculus of variations]. Moscow, Nauka, 1996.

3. Moiseev N.N. Issledovanie operacij. Zadachi, principy, metodologija [Research operations. Tasks, principles, methodology]. Moscow, Nauka, 1988.

4. Tabunshchikov Yu.A. O protivorechivosti trebovanij $\mathrm{k}$ teplozashhite zdanij $\mathrm{v}$ letnih $\mathrm{i}$ zimnih uslovijah [On the inconsistency of the requirements for thermal protection of buildings in summer and winter conditions]. // AVOK, 2013, No. 3.

5. Korobeinik Yu.F., Tabunshchikov Yu.A. Ob odnoj zadache linejnogo upravlenija i ee prilozhenii k teplotehnike [On a linear control problem and its application to heat engineering]. Moscow, AVOK-PRESS, 2002. 


\section{СПИСОК ЛИТЕРАТУРЫ}

1. Табунщиков Ю.А., Бродач М.М. Математическое моделирование и оптимизация тепловой эффективности зданий. М.: АВОК-ПРЕСС, 2002. - 194 с.

2. Эльсгольц Л.Э. Дифференциальные уравнения и вариационное исчисление. М.: Наука, 1996.

3. Моисеев Н.Н. Исследование операций. Задачи, принципы, методология. - М.: Наука, 1988.

4. Табунщиков Ю.А. О противоречивости требований к теплозащите зданий в летних и зимних условиях. // $A B O K, 2013$, №3.

5. Коробейник Ю.Ф., Табунщиков Ю.А. Об одной задаче линейного управления и ее приложении к теплотехнике. - М.: АВОК-ПРЕСС, 2002.

Yuri A. Tabunshchikov, Corresponding Member of the Russian Academy of Architecture and Construction Sciences (RAACN), Professor, D.Sc.; Head of the Department of Engineering Equipment of Buildings and Structures, Moscow Architectural Institute (State Academy); room 305, 11, building 1, Rozhdestvenka Street, Moscow, 107031, Russia; phone: +7 (495) 625-16-67;

Email: tabunschikov@abok.ru.

Brodach Marianna Mikhailovna, Professor, Ph.D.; Professor of the Department of Engineering Equipment of Buildings and Structures, Moscow Architectural Institute (State Academy); room 305, 11, building 1, Rozhdestvenka Street, Moscow, 107031, Russia;

phone: +7 (495) 625-16-67;

Email: brodatch@abok.ru.

Табунщиков Юрий Андреевич, член-корреспондент Российской академии архитектуры и строительных наук (РАACH), профессор, доктор технических наук; заведующий кафедрой «Инженерное оборудование зданий и сооружений», Московский архитектурный институт (государственная академия); 107031, Россия, Москва, улица Рождественка, дом 11, 1 корпус, помещение 305; телефон: +7(495)625-16-67;

Email: tabunschikov@abok.ru.

Бродач Марианна Михайловна, профессор, кандидат технических наук; профессор кафедры «Инженерное оборудование зданий и сооружений», Московский архитектурный институт (государственная академия);

Volume 16, Issue 1, 2020
107031, Россия, Москва, улица Рождественка, дом 11, 1 корпус, помещение 305; телефон: +7(495)625-16-67; Email: brodatch@abok.ru. 